\title{
Characterization of lacZ Complementation Deletions Using Membrane Receptor Dimerization
}

\author{
D. Thormeyer, \\ O. Ammerpohl ${ }^{1}$, O. Larsson, \\ Y. Xu, A. Asinger, \\ C. Wahlestedt, and Z. Liang \\ Karolinska Institute and \\ ${ }^{1}$ Karolinska Hospital, \\ Stockholm, Sweden
}

\section{INTRODUCTION}

The $\alpha$ complementation of the bacterial lacZ gene (encoding $\beta$-galactosidase, or $\beta$-gal) has been studied for 30 years in prokaryotes $(7-9,17)$ and has recently been adapted for the use in eukaryotes $(13,15)$. Two weakly complementing mutants of $\beta$-gal, $\Delta \alpha$ and $\Delta \omega$, were used to detect interactions between cytoplasmic protein $(12,15)$ and membrane protein (2) in living mammalian cells. The $\beta$-gal mutants were fused to different target proteins, and the interaction of the non- $\beta$-gal portions of the chimeric proteins were found to be able to restore the complementation capacity of $\Delta \alpha$ and $\Delta \omega$. Thus, the reconstitution of the $\beta$-gal activity was taken as an indicator of the interaction between the target proteins.

While the two-hybrid system has been widely used for exploring interactions between soluble proteins, the study of interactions between different membrane proteins and membrane proteins and their ligands has lagged behind because of the lack of robust assay methodology. We have attempted to implement a plasmid-based assay to study the interactions between $G$ protein-coupled receptor (GPCR) using $\Delta \alpha$ and $\Delta \omega$ instead of $\beta$-gal, but we observed significant spontaneous $\alpha$-complementation from the co-expressed mutants even when they were not fused to any peptides. This background signal made it difficult for the method to be employed in high-throughput applications.

Here we screened for novel $\beta$-gal deletions in living mammalian cells that could reduce such background. We discovered a pair of deletions, $\Delta \mathrm{N} 11$ 75 and $\Delta \mathrm{C}$ 82-1023, which showed significantly lower spontaneous complementation when co-expressed transiently in mammalian cells. This pair of deletions was first characterized using affinity peptides and the human insulin receptor (IR) as model systems to perform homodimerization studies. We then examined the dimerization state of the rat adrenergic receptor $\alpha_{2}$-receptor subtype $\alpha_{2 \mathrm{c}} \mathrm{AR}$ and the rat D2 dopamine receptor $\left(D_{2} \mathrm{DR}_{\mathrm{L}}\right)$ using this pair of lacZ deletions. Here we found histochemical evidence that $\alpha_{2 \mathrm{c}} \mathrm{AR}$ homodimerizes in vivo. Although different techniques have been used to examine rat $\mathrm{D} 2 \mathrm{DR}_{\mathrm{L}}$ dimerization $(14,21)$, we are the first to report that $\mathrm{D} 2 \mathrm{DR}$ forms homodimers in living mammalian cells. Our results suggest that the combination of a plasmid-based assay system with the novel lacZ deletions could provide a high-throughput system in which the interaction between different membrane receptors and its localization could be analyzed in a rapid and sensitive manner.

\section{MATERIALS AND METHODS}

\section{Expression Plasmids Encoding for $\Delta \mathrm{N} 11-30, \Delta \mathrm{N} 11-41$, and $\Delta \mathrm{N} 11-75$}

$\Delta \mathrm{N} 11-41$ was first cloned by the fusion of the BamHI filled-in XhoI fragment from the previously described lacZ construct $\mathrm{pWZL} \Delta \alpha$ into the $X b a \mathrm{I}$ filled-in XhoI site of the His-tagged pcDNA3.1 (Interactiva). To design the $\Delta \mathrm{N}$ deletion mutants $\Delta \mathrm{N} 11-30$ and $\Delta \mathrm{N}$ 
11-75, the coding region for the construct pWZL $\Delta \omega$ (15) was cloned by the insertion of the XhoI-EcoRV fragment from $\mathrm{pWZL} \Delta \omega$ into the PstI filled-in XhoI site of Bluescript ${ }^{\circledR} \mathrm{SK}\left({ }^{+}\right.$) (Stratagene, La Jolla, CA, USA). The deletion mutants $\Delta \mathrm{N} 11-30$ and $\Delta \mathrm{N} 11-75$ were constructed by PCR with the primers $\Delta \mathrm{N} 11$ reverse (Interactiva) and $\Delta \mathrm{N} 30$ forward $(\Delta \mathrm{N} 11-30) ; \Delta \mathrm{N} 11$ reverse and $\Delta \mathrm{N} 75$ forward $(\Delta \mathrm{N} 11-75)$. (Table 1 summarizes all the sequences of the primers and other syntheitic oligonucleotides.) The PCR products were digested with $D p n I$, ligated, and checked by DNA sequencing with $\mathrm{T} 7$ primer (Interactiva) using DYEnamic ET Terminator Cycle Sequencing Kit (Amersham Biosciences, Piscataway, NJ, USA). Both deletion mutants were inserted in frame right after the His-tag of $\Delta \mathrm{N} 11-41$ by fusion of the XhoI-Bsu36I fragments from $\mathrm{pBSK}\left({ }^{+}\right) \Delta \mathrm{N} 11-30$ and $\left.\operatorname{pBSK}^{+}\right) \Delta \mathrm{N}$ 11-75 into the XhoIBsu36I site of $\Delta \mathrm{N} 11-41$.

Expression Plasmids Coding for $\Delta \mathrm{C}$ 46-1023, $\Delta C$ 82-1023, $\Delta C$ 148-1023, $\Delta C$ 377-1023, $\Delta C$ 653-1023, and $\Delta C$ 789-1023

To design the $\Delta \mathrm{C}$ deletion mutants, the coding region for the construct $\mathrm{pWZL} \Delta \omega$ was cloned first by the fusion of the Bsp120I filled-in XhoI fragment in frame into the $X b a$ I filled-in XhoI site of pcDNA3.1/Hygro $(+)$ (Interactiva) ( $\Delta \omega$ 89-1023). This construct was used as a template for PCR to design the deletion mutant $\Delta \mathrm{C} 46-1023$ with the primers $\Delta \mathrm{C} 46$ forward and $\Delta \mathrm{C} 46$ reverse (Table 1), which included three stop-codons at the $3^{\prime}$ end. The PCR product was digested with $X h o \mathrm{I}$ and cloned into the ApaI filled-in XhoI site of pcDNA3.1/Hygro(+). $\Delta \mathrm{C}$ 46-1023 was digested with $X b a$ I filled-in- $X h o I$ to insert the Bsu36I filled-in-XhoI fragment from $\Delta \mathrm{C}$ 789-1023 to design the construct $\Delta \omega$ 82-1023. $\Delta \mathrm{C} \quad 148-1023$ was constructed by the insertion of the XhoI-HpaI fragment from $\Delta \omega$ 789-1023 into the $X b a \mathrm{I}$ filled-in $X h o \mathrm{I}$ site of $\Delta \mathrm{C}$ 46-1023. $\Delta$ C 377-1023 was constructed by the insertion of the XhoI-EcoRV fragment from $\Delta C$ 789-1023 into the $X b a$ I filled-in XhoI site of $\Delta \mathrm{C} 46-1023$. $\Delta \mathrm{C}$ 653-1023 was constructed by the insertion of the SacI filled-in XhoI frag-

Table 1. Primers and Other Short Synthetic DNA Sequences

\begin{tabular}{ll}
$\begin{array}{l}\text { Name of the } \\
\text { Oligonucleotides }\end{array}$ & \multicolumn{1}{c|}{$\begin{array}{c}\text { Sequences of the Primer } \\
\left(\mathbf{5}^{\prime} \rightarrow \mathbf{3}^{\prime}\right)\end{array}$} \\
$\begin{array}{l}\Delta \mathrm{N} 11 \text { rev. } \\
\Delta \mathrm{N} 30 \text { forw. }\end{array}$ & GACGGCCAGTGAATCCGTA \\
$\Delta \mathrm{N} 75$ forw. & GAGTGCGATCTTCCTGAGGCC \\
ARprim1 & GTAAGGTACCCATGGGCTCCCTGCAGC \\
ARprim2 & ATTCCTCGAGCACGATGCGCTTTCTGTCCC \\
D2prim1 & CTCCTCATCTTTATCATCGTC \\
D2prim2 & CTTTCTGCGGCTCATCGT \\
$\Delta \mathrm{C} 46$ forw. & CTGCAGATATCCAGCACAGTGG \\
$\Delta \mathrm{C} 46$ rev. & TCAGCTAGTTATCTAGAGCGGGCCTCTTCGCTATTAC \\
PepA(+) & CTATGAACGAAGCATATGTACATGACGGTCCTGTACGC- \\
PepA(-) & TCACTGAACC \\
PepB(+) & TTCGTTCATAG \\
PepB(-) & ATGAAGGCACGAAAGGAAGCAGAACTGGCAGCAGCA- \\
& GCTGTTCTGCAGTTGCTGCTGCCAGTTCTGCTTCCTT- \\
Rev., reverse; forw., forward.
\end{tabular}

ment from $\Delta \mathrm{C} 789-1023$ into the $X b a \mathrm{I}$ filled-in $X h o$ I site of $\Delta \mathrm{C} 46-1023$.

\section{Design of the pepA- $\Delta \mathrm{N}$ - and pepB- $\Delta \mathrm{C}$ Constructs}

For the expression of pepA (MNEAYVHDGPVRSLN) and pepB (MKARKEAELAAATAEQ), oligonucleotides were designed with the coding sequence pep $\mathrm{A}(+)$ and pepA(-), and $\operatorname{pepB}(+)$ and pepB(-) (Interactiva) (Table 1). The annealed oligonucleotide sequences expressing pepA and pepB were cloned into the bluntended EcoRV sites from His-tagged pcDNA3.1 and pcDNA3.1/Hygro $(+)$. pepA- $\Delta$ N 11-30, pepA- $\Delta$ N 11-41, and pepA- $\Delta \mathrm{N} 11-75$ were constructed by the fusion of the ApaI-XhoI fragments from the His-tagged pcDNA3.1 constructs $\Delta \mathrm{N} 11-30, \Delta \mathrm{N} 11-41$, and $\Delta \mathrm{N}$ 11-75 into the ApaI-XhoI site of pepApcDNA3.1. To create the pepB- $\Delta \mathrm{C}$ constructs, pepB- $\Delta$ C 46-1023 was first created by a three-fragment ligation: the vector $\Delta C$ 46-1023, which was cut with HindIII-XhoI, was ligated to both the XmaI filled-in HindIII fragment from HA-tagged pcDNA3.1/Hygro(+), which encompasses the HA-tag coding sequence, and to the EcoRI filled-in $X h o$ I fragment encoding the pepB fusion from pepB-pcDNA3.1/Hygro(+) that was cloned immediately after the HA-tag. For the design of pepB-fused $\Delta \mathrm{C}$ 82-1023, $-\Delta \mathrm{C}$ 148-1023, $-\Delta \mathrm{C} 377-$ $1023,-\Delta \mathrm{C}$ 653-1023, and $-\Delta \mathrm{C} 789-$ 1023 , the vector pepB- $\Delta C$ 46-1023 was digested with $X b a \mathrm{I}$ filled-in $\mathrm{XhoI}$ to insert the fragments that were cut with the same restriction enzymes as described earlier for the design of the non pepB- $\Delta \mathrm{C}$ constructs.

\section{Construction of $\alpha_{2 \mathrm{c}} \mathrm{AR}-\Delta \mathrm{N}$ 11-75, $\alpha_{2 \mathrm{c}} \mathrm{AR}-\Delta \mathrm{C}$ 82-1023, D2DR $\mathrm{L}_{\mathrm{L}}-\Delta \mathrm{N}$ 11- 75, D2DR $\mathrm{L}_{\mathrm{L}}-\Delta \mathrm{C}$ 82-1023, IR- $\Delta \mathrm{N}$ 11- 75, and IR- $\Delta$ C 82-1023}

The coding region of rat $\alpha_{2 c} \mathrm{AR}$ was amplified from $R \alpha_{2} p R c / C M V$ (19) by PCR with the primers ARprim1 and ARprim2 (Table 1). The PCR product was cloned in frame into the blunt-ended $K p n \mathrm{I}-X h o \mathrm{I}$ site from $\Delta \mathrm{N} 11-75$, directly in front of the lacZ deletion mutant $\alpha_{2 \mathrm{c}} \mathrm{AR}-\Delta \mathrm{N} 11-75$, and verified by DNA sequencing. $\alpha_{2 \mathrm{c}}$ AR- $\Delta \mathrm{C}$ 82-1023 was generated by insertion of the HindIII-XhoI fragment from $\alpha_{2 \mathrm{c}} \mathrm{AR}-\Delta \mathrm{N} 11$ 75 into the HindIII-XhoI site of $\Delta \mathrm{C} 82$ - 
1023 , directly in front of the lacZ deletion mutant. The coding region for rat $\mathrm{D}_{2} \mathrm{DR}_{\mathrm{L}}$ was amplified from $\mathrm{pBSK}\left({ }^{+}\right)$ $\mathrm{D}_{2} \mathrm{DR}_{\mathrm{L}}$ (5) by PCR with the primers D2prim1 and D2prim2 (Table 1). The PCR product was cloned in frame into the blunt-ended $K p n \mathrm{I}-X h o \mathrm{I}$ site from $\Delta \mathrm{N}$ $11-75$, directly in front of the lacZ deletion mutant to design $\mathrm{D}_{2} \mathrm{DR}_{\mathrm{L}}-\Delta \mathrm{N} 11$ 75 , and verified by DNA sequencing. $\mathrm{D}_{2} \mathrm{DR}_{\mathrm{L}}-\Delta \mathrm{C} 82-1023$ was generated by the insertion of the KpnI-XhoI fragment from $\mathrm{D}_{2} \mathrm{DR}_{\mathrm{L}}-\Delta \mathrm{N} 11-75$ into the $K p n \mathrm{I}-$ XhoI site of $\Delta \mathrm{C} 82-1023$. IR- $\Delta \mathrm{N}$ 11-75 and IR- $\Delta$ C $82-1023$ were created by the insertion of the HindIII-FspI fragment from pcRCMVi IR(A) (10) in frame into the XhoI filled-in HindIII site of $\Delta \mathrm{N} 11-$ 75 and $\Delta C$ 82-1023.

DNA Construction of EGFP- $\Delta$ N 1175, $\alpha_{2 \mathrm{c}}$ AR-EGFP- $\Delta$ N 11-75, D2DR $_{\mathrm{L}^{-}}$ EGFP- $\Delta$ N 11-75, IR-EGFP- $\Delta$ N 1175, Red2- $\Delta$ C 82-1023,

$\alpha_{2 \mathrm{c}}$ AR-Red2- $\Delta$ C 82-1023, D2DR ${ }_{\mathrm{L}}$ Red2- $\Delta$ C 82-1023, and IR-Red2- $\Delta C$ 82-1023

EGFP- $\Delta \mathrm{N}$ 11-75, $\alpha_{2 \mathrm{c}}$ AR-EGFP$\Delta \mathrm{N} 11-75$, and D2DR ${ }_{\mathrm{L}}-\mathrm{EGFP}-\Delta \mathrm{N} 11-$ 75 were constructed by the insertion of the $B g l$ II-Eco47III fragment from pEGFP-C3 [enhanced GFP (EGFP); BD Biosciences Clontech, Palo Alto, CA, USA] into the blunt-ended XhoI site of $\Delta \mathrm{N} 11-75, \alpha_{2 \mathrm{c}}$ AR- $\Delta \mathrm{N}$ 11-75, and D2DR $\mathrm{L}_{\mathrm{L}}-\Delta \mathrm{N}$ 11-75. IR-EGFP- $\Delta \mathrm{N}$ 11-75 was created by the fusion of the HindIII-Fs $p$ I fragment from pcRCMVIR into the NotI filled-in HindIII site of EGFP- $\Delta \mathrm{N}$ 11-75. Red2- $\Delta \mathrm{C}$ 821023, $\alpha_{2 c}$ AR-Red2- $\Delta$ C 82-1023, and $\mathrm{D}_{2} \mathrm{DR}_{\mathrm{L}}-\mathrm{Red} 2-\Delta \mathrm{C}$ 82-1023 were constructed by the insertion of the EcoRIEco47III fragment from pDsRed2-C1 (BD Biosciences Clontech) into the blunt-ended XhoI site of $\Delta \mathrm{C} 82-1023$, $\alpha_{2 \mathrm{c}}$ AR- $\Delta \mathrm{C}$ 82-1023, and D2DR $\mathrm{L}_{\mathrm{L}}-\Delta \mathrm{C}$ 82-1023. IR-Red2- $\Delta$ C 82-1023 was generated by a three-fragment ligation: the vector Red2- $\Delta$ C 82-1023, cut with HindIII, was ligated to both the HindIII- $F s p$ I fragment from pcRCMV-IR, encompassing the IR coding sequence, and to the NotI filled-in HindIII fragment encoding the Red2 sequence from Red2- $\Delta$ C 82-1023. All chimeric constructs were checked by DNA sequencing.

\section{Cell Culture}

Human embryonic kidney (HEK)293 cells were grown in DMEM (Sigma, St. Louis, MO, USA) supplemented with $10 \% \mathrm{FBS}$ and $1 \%$ penicillin $(10000 \mathrm{U} / \mathrm{mL}) /$ streptomycin $\quad(10000$ $\mathrm{mg} / \mathrm{mL}$ ) at $37^{\circ} \mathrm{C}$ in a humidified $5 \%$ $\mathrm{CO}_{2}$ atmosphere. Cells were seeded at a density of $2-3 \times 10^{5}$ cells per 24 -well plate (Greiner).

Transient transfection was performed the following day with 0.2 pmol cDNA (individually or in combination) by using TransFast ${ }^{\mathrm{TM}}$ Transfection Reagent (Promega, Madison, WI, USA) according to the manufacturer's instructions. After $48 \mathrm{~h}$, the cells were prepared for further experiments. All experiments were done in triplicate. The efficiency of the transfection for all constructs was found to be in similar range, as indicated by the co-transfection of a firefly luciferase plasmid.

\section{Indigogenic X-Gal Histochemistry for $\beta$-gal}

Cells were processed as described (12). Briefly, cells were fixed for $5 \mathrm{~min}$ in PBS plus 4\% paraformaldehyde and rinsed in PBS before staining. Indigogenic X-gal staining was performed for $45 \mathrm{~min}$ to $4 \mathrm{~h}$ at $37^{\circ} \mathrm{C}$ in PBS, plus 1 $\mathrm{mg} / \mathrm{mL} \mathrm{X-gal,} 1 \mathrm{mM} \mathrm{MgCl} 2,5 \mathrm{mM}$ $\mathrm{K}_{3} \mathrm{Fe}(\mathrm{CN})_{6}$, and $5 \mathrm{mM} \mathrm{K}_{4} \mathrm{Fe}(\mathrm{CN})_{6}$.

\section{Fluorescence Microscopy}

Fluorescence microscopy was performed on a Leica DM RXA microscope using a Leica $40 x / 1.25$ oil numerical aperture. HEK-293 cells expressing EGFP- $\Delta \mathrm{N} 11-75, \alpha_{2 c} \mathrm{AR}-$ EGFP- $\Delta \mathrm{N}$ 11-75, D2DR - EGFP- $\Delta \mathrm{N}$ 11-75, IR-EGFP- $\Delta$ N 11-75, Red2- $\Delta$ C 82-1023, $\alpha_{2 c}$ AR-Red2- $\Delta$ C 82-1023, $\mathrm{D}_{2} \mathrm{DR}_{\mathrm{L}}-\mathrm{Red} 2-\Delta \mathrm{C}$ 82-1023, and IRRed2- $\Delta$ C 82-1023, individually or in combination, were grown on 24-well glass-bottomed culture plates. After 48 $\mathrm{h}$, the cells were washed twice with PBS, and the subcellular distribution of chimeric- and non-chimeric EGFP and Red 2 constructs were detected using single-line excitation at 488 and 558 $\mathrm{nm}$. Co-localization studies of these constructs were performed using dualline switching excitation (488 nm for
EGFP; $588 \mathrm{~nm}$ for Red2) and emission (500-550 nm GFP; 572-648 nm Cy3) filter sets, and images represented in false color using Adobe ${ }^{\circledR}$ Photoshop ${ }^{\circledR}$ 5.0 software.

\section{FACS ${ }^{\circledR}$ Analysis}

After one wash with PBS, HEK-293 cells were trypsinized, pelleted, resuspended in staining medium (4\% FCS, $10 \mathrm{mM}$ HEPES, $\mathrm{pH}$ 7.3, and PBS), and adjusted to $5-10 \times 10^{6}$ cells $/ \mathrm{mL}$. The cell suspension $(100 \mu \mathrm{L})$ was transferred to a Falcon 2058 tube. After the cells had been allowed to equilibrate in a water bath at $37^{\circ} \mathrm{C}$ for $10 \mathrm{~min}$, an equal volume of pre-warmed $2 \mathrm{mM}$ fluorescein di- $\beta$-D-galactopyranoside (FDG; Molecular Probes, Eugene, OR, USA) was rapidly mixed with the cell suspension. After $1 \mathrm{~min}$ of incubation at $37^{\circ} \mathrm{C}$, the FDG loading was stopped by the addition of $2 \mathrm{~mL}$ ice-cold staining media containing $1 \mu \mathrm{g} / \mathrm{mL}$ propidium iodide (PI; Sigma), and the tube was placed on ice. The cells were left on ice for 2-3 $\mathrm{h}$ to allow for the enzymatic conversion of FDG to fluorescein. These samples were run on a FACScan ${ }^{\circledR}$ Cell Analyzer (BD Biosciences, San Jose, CA, USA).

\section{Colorimetric $\beta$-gal Assay}

HEK-293 cells were trypsinized and resuspended in medium (4\% FCS, 10 mM HEPES, $\mathrm{pH} 7.3$, PBS $)$. Cells $(2 \times$ $\left.10^{5}\right)$ were incubated with $2 \mathrm{mM}$ FDG for $1 \mathrm{~min}$ at $37^{\circ} \mathrm{C}$. The FDG loading was stopped by the addition of $2 \mathrm{~mL}$ ice-cold medium, and the cells were placed on ice for $3 \mathrm{~h}$. After pelleting the cells, the enzymatic conversion of FDG to fluorescein was determined photometrically at $485 \mathrm{~nm}$.

\section{RESULTS AND DISCUSSION}

\section{Design and Screening of a Novel Pair of lacZ Deletions}

The transient co-transfection of the previously described weakly complementing $\Delta \alpha 11-41$ and $\Delta \omega 789-1023$ deletion mutants $(2,12,15)$ generated a high-background $\beta$-gal activity in HEK-293 and NIH-3T3 cells in our ex- 
periments (data not shown). Therefore, we constructed plasmids expressing several novel amino (N)- and carboxyl (C)-terminal-deleted versions (called $\Delta \mathrm{N}$ and $\Delta \mathrm{C}$ ) of lacZ (Figure 1A). Our goal was to find pairs of inactive $\beta$-gal deletion mutants that were capable of complementing one another in trans and assembling to form an active enzymatic complex only in the presence of interacting peptides. Chimeric proteins were formed between the lacZ deletions and a pair of small interacting peptides, pepA and pepB, in the first instance. The two peptides were recently isolated from a library using a $\lambda$ repres- sor-reconstitution assay (22) and were chosen for this study because their small size could minimize the risk of influencing the protein structure of the tested lacZ deletions and avoid nonspecific $\beta$-gal activity. PepA (MNEAYVHDGPVRSLN) was fused to the $\Delta \mathrm{N}$ constructs (Figure 1B), and pepB (MKARKEAELAAATAEQ) was fused to the designed $\triangle \mathrm{C}$ constructs.

All $\Delta \mathrm{N}$ and $\Delta \mathrm{C}$ constructs were transiently co-transfected pairwise into HEK-293 cells to screen for $\beta$-gal deletion mutants that displayed a low level of spontaneous complementation when co-expressed as non-chimeric proteins.
The degree of spontaneous complementation was quantified by counting the numbers of cells stained blue in the presence of X-gal. No blue-stained cells were detected for the deletion mutants $\Delta \mathrm{N} 11-75$ and $\Delta \mathrm{C} 46-1023$ when co-expressed with or without the chimeric peptides (Figure 1C, right panel, background) because the lack of 29 amino acids prevented the formation of an active enzyme complex. The previously described weakly complementing deletion mutants $\Delta \alpha 11-41$ and $\Delta \omega 789$ 1023 showed a high level of $\beta$-gal activity with more than $400 \mathrm{X}$-gal-positive cells in this assay, even with no

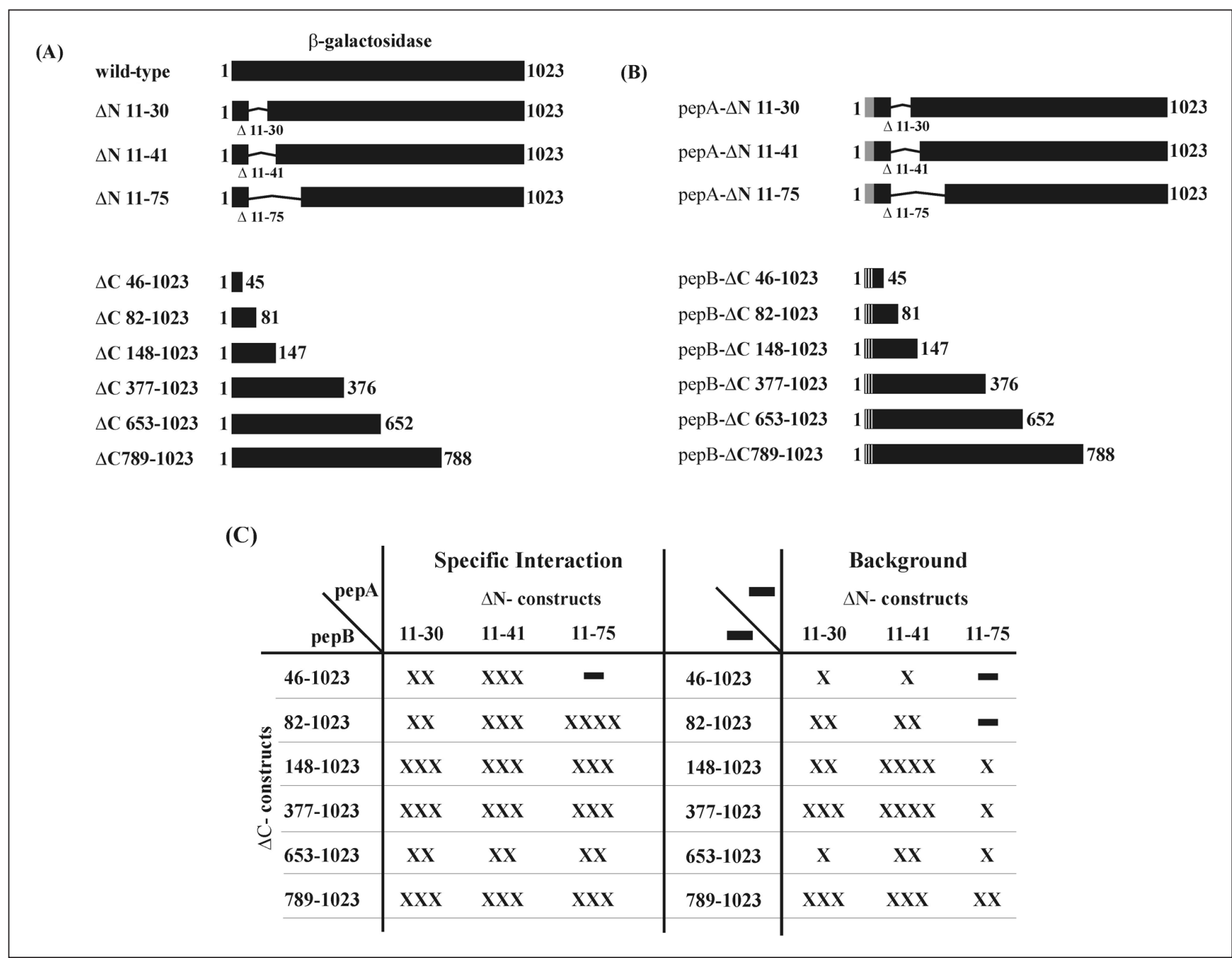

Figure 1. Schematic representation of various deletion mutants derived from wild-type $E$. coli LacZ and the effects of their transient transfection in HEK-293 cells. (A and B) Black bars show native lacZ sequences; black line, deleted region in our $\Delta N$ constructs. The indicated numbers represent the positions of the amino acids. The chimeric $\Delta \mathrm{N}$ and $\Delta \mathrm{C}$ constructs are shown as gray areas that describe the protein pepA. The striped area represents the protein pepB. (C) Scheme for the results of histochemical assays of the induction of $\beta$-gal activity upon chimeric complementation. Equimolar amounts of $\Delta \mathrm{N}$ and $\Delta \mathrm{C}$ expression vectors or pepA- $\Delta \mathrm{N}$ and pepB- $\Delta \mathrm{C}$ constructs were co-transfected pairwise, and after $48 \mathrm{~h}$, the cells were stained with $\mathrm{X}$-gal and visualized under a microscope. Average numbers of blue-stained cells in five view fields were quantitatively determined as followed: $\mathrm{xxxx}$ (more than 300 blue cells); xxx (beween 200 and 300); xx (between 100 and 200); x (between 10 and 100); and - (less than 10). 
chimeric peptides. Only a novel pair of lacZ deletions, $\Delta \mathrm{N} 11-75$ and $\Delta \mathrm{C}$ 821023, were found to fulfill our selection criteria: the lowest background when co-expressed as non-fusion proteins and high signal when fused with interacting peptides. For $\Delta \mathrm{N} 11-75$ and $\Delta \mathrm{C}$ 821023 , fewer than 10 blue cells were observed when the lacZ deletions were not fused to the peptides, whereas 30 times more blue cells were found when the lacZ deletions were attached to the pepA and pepB (Figure 1C, left panel). Note that all deletions could find at least one complementation partner. This proved that none of the deletions was deficient in accumulation (Figure 1C).

\section{Induction of $\beta$-gal Activity on Co-Expressed IR when Fused to the Deletions $\Delta N$ 11-75 and $\Delta C$ 82-1023}

We first chose IR to test the applicability of our novel lacZ deletions in the study of membrane protein interaction because it is known that IR, a tyrosine kinase, is internalized as a dimer at the cell surface $(6,16,18)$. HEK-293 cells were co-transfected with equimolar amounts of IR- $\Delta \mathrm{N}$ 11-75 and IR- $\Delta \mathrm{C}$ 82-1023 simultaneously or individually, and then X-gal staining was used to visualize the reconstitution of the $\beta$-gal activity. The results showed a high proportion of blue-stained cells when both chimeric receptors were co-transfected, indicating that they interacted with each other (Figure 2A). In comparison, only a few cells were X-gal-positive when both constructs $\Delta \mathrm{N} 11-75$ and $\Delta \mathrm{C}$ 82-1023 were co-expressed as non-fusion proteins (Figure 2B). In cells that expressed only one of the two chimeric constructs, no $\beta$-gal activity could be detected (Figure 2, C and D). These results were corroborated by the FACS analysis of the cell populations co-expressed with IR-fused $\Delta \mathrm{N} 11-75$ and $\Delta \mathrm{C}$ 82-1023 construct pair and, as negative controls, the non-fused proteins $\Delta \mathrm{N} 11-75$ and $\Delta \mathrm{C} 82-1023$ pair (Figure 2E). IR-fused and non-fused $\Delta \alpha 11-41$ and $\Delta \omega 789-1023$ construct pairs were also included for a comparison (Figure $2 \mathrm{~F}$ ). The assay clearly showed a much higher $\beta$-gal activity for the IR-fused $\Delta \mathrm{N} 11-75$ and $\Delta \mathrm{C}$ 82-1023 construct pair compared to the non-fused proteins $\Delta \mathrm{N} 11-75$ and $\Delta \mathrm{C} 82-1023$ pair, in which the peak overlapped completely with the peak generated by untransfected cells (data not shown). The $\beta$-gal activity was not significantly different between the cells that were co-transfected IR-fused and non-fused $\Delta \alpha 11-41$ and $\Delta \omega 789-1023$ construct pairs.

To verify the localization of the fusion proteins, IR- $\Delta \mathrm{N}$ 11-75 was further fused to the EGFP derived from $\mathrm{Ae}$ quorea victoria, whereas IR- $\Delta \mathrm{C}$ 821023 was further fused to the red fluo- rescent protein (Red2) derived from Discosoma sp. The constructs were transfected into HEK-293 cells individually or simultaneously, and the localization of the fusion proteins was visualized by fluorescence microscopy. The results demonstrated that both IREGFP- $\Delta$ N 11-75 (Figure 2G) and IRRed2 $\Delta$ C 82-1023 (Figure 2H) showed a non-ambiguous distribution to the cell membrane, although the receptors were also found intracellularly as clusters

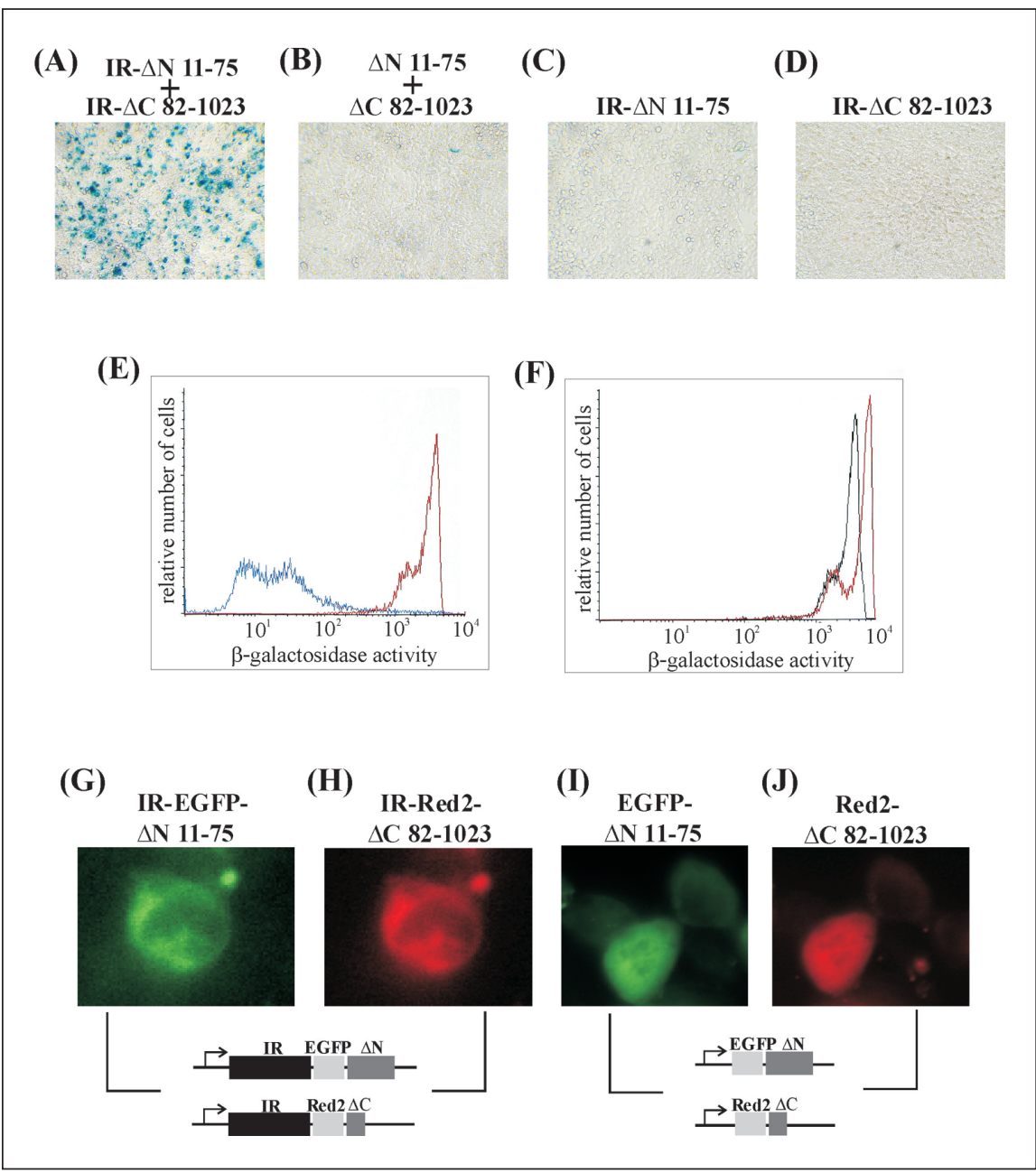

Figure 2. Dimerization studies of the human IR when fused to the lacZ deletions $\Delta \mathrm{N}$ 11-75 and $\Delta \mathrm{C}$ 82-1023 in HEK-293 cells. Reconstitution of $\beta$-gal activity on chimeric complementation was monitored by X-gal staining. The enzymatic reactions with X-gal were stopped after $127 \mathrm{~min}$ and visualized by microscopy. The blue-stained cells are an indicator that the receptor forms a dimer within the cells (A). No $\beta$-gal activity was detected for the non-fused co-expressed lacZ deletions $\Delta \mathrm{N}$ 11-75 and $\Delta \mathrm{C} 82$ 1023 (B) or for the separately expressed chimeric receptor pairs (C and D). (E and F) FACS analysis of $\beta$ gal activity upon chimeric complementation. The blue cell frequency and the level of $\beta$-gal activity were expressed as a blue line for $\Delta \mathrm{N} 11-75$ and $\Delta \mathrm{C} 82-1023$, a red line for the chimeric receptor pair IR- $\Delta \mathrm{N}$ 11-75 and IR- $\Delta \mathrm{C}$ 82-1023 (E), and a black line for $\Delta \alpha 11-41$ and $\Delta \omega$ 789-1023 (F). The vertical axis represents the relative cell number, and the horizontal axis represents the intensity of $\beta$-gal fluorescence on a logarithmic scale. The localization of the chimeric proteins was monitored by fluorescence microscopy. Representative cells show the membrane distribution of the co-expressed membrane receptor IR-EGFP$\Delta \mathrm{N}$ 11-75- (G) and IR-Red2- $\Delta \mathrm{C}$ 82-1023 (H), and for the co-expressed lacZ deletions EGFP- $\Delta \mathrm{N}$ 11-75 (I) and Red2- $\Delta \mathrm{C}$ 82-1023 (J). 
that were possibly associated with intracellular compartments or vesicles. This was in clear contrast to the cytoplasmic distribution observed for the lacZ deletions EGFP- $\Delta \mathrm{N} 11-75$ (Figure 2I) and Red2- $\Delta$ C 82-1023 (Figure 2J). It is worth mentioning that the insertion of EGFP and Red2 into the receptor constructs did not lead to a destruction of the enzymatic $\beta$-gal complex because the addition of X-gal still resulted in blue-stained cells (data not shown). This feature allows us to analyze simultaneously both the dimerization and localization in a single cell.

\section{$\alpha_{2 c} \mathrm{AR}$ and $\mathrm{D2DR}_{\mathrm{L}}$ Dimerization Monitored by Using $\beta$-Gal Complementation}

We further characterized the assay system by using it to investigate the protein-protein interactions of GPCRs using $\alpha_{2 c} A R$ and $D_{2} \mathrm{DR}_{\mathrm{L}}$ as target genes. HEK-293 cells were co-transfected with equimolar amounts of $\alpha_{2 \mathrm{c}}$ AR- $\Delta \mathrm{N} 11-75$ and $\alpha_{2 \mathrm{c}}$ AR- $\Delta$ C 82 1023 or with $\mathrm{D}_{2} \mathrm{DR}_{\mathrm{L}}-\Delta \mathrm{N} 11-75$ and $\mathrm{D}_{2} \mathrm{DR}_{\mathrm{L}}-\Delta \mathrm{C}$ 82-1023 simultaneously or individually, with non-fusion $\Delta \mathrm{N} 11-75$ and $\Delta \mathrm{C} 82-1023$ as negative controls. Only a few cells were stained blue in the presence of X-gal when both nonfusion $\Delta \mathrm{N} \mathrm{11-75}$ and $\Delta \mathrm{C}$ 82-1023 constructs were co-expressed (Figure 3B). Fusion to $\alpha_{2 c} A R$ elevated the number of blue-stained cells significantly (Figure 3A). Similar but moderate increases were also observed for D2DR $\mathrm{L}_{\mathrm{L}}$ fusions. The enzymatic reactions for $\mathrm{D}_{2} \mathrm{DR}_{\mathrm{L}}$ fusions were carried out for a longer time due to the weaker signal obtained from these constructs, but this did not change the major conclusions about either the homodimerization of the $\mathrm{D} 2 \mathrm{DR} \mathrm{R}_{\mathrm{L}}$ or the applicability of the $\Delta \mathrm{N} \mathrm{11-75}$ and $\Delta \mathrm{C}$ 82-1023 mutants in such assays. No $\beta$-gal activity could be detected when only one of the two chimeric constructs was expressed (Figure 3, C and D). FACS analysis and colormetric $\beta$-gal activity assay provided a more quantitative confirmation to this conclusion. Cell populations co-expressed with $\alpha_{2 c} A R-$ or D2DR $\mathrm{L}_{\mathrm{L}}$-fused $\Delta \mathrm{N} 11-75$ and $\Delta \mathrm{C}$ 82-1023 construct pairs showed a $\beta$-gal activity that was elevated from $10\left(\mathrm{D} 2 \mathrm{RD}_{\mathrm{L}}\right)$ to 100 times $\left(\alpha_{2 \mathrm{c}} \mathrm{AR}\right)$ (Figure $\left.4 \mathrm{~A}\right)$. The colorimetric measurement of $\beta$-gal activity confirmed that the enzyme activity was elevated 10-fold (D2DR $\mathrm{L}_{\mathrm{L}}$ ), 35 times (IR), and 125 times $\left(\alpha_{2 c} \mathrm{AR}\right)$, respectively, by the homodimerization of the fusion proteins compared to the non-fused $\Delta \mathrm{N}$ 11-75 and $\Delta \mathrm{C} 82-1023$ pairs. No $\beta$-gal activity could be detected when only one of the two chimeric IR, $\alpha_{2 c} \mathrm{AR}$, and $\mathrm{D}_{2} \mathrm{DR}_{\mathrm{L}}$ constructs were expressed (Figure 4B).

We also co-transfected fusion constructs for different target proteins to study how different membrane proteins interact with each other. A weak but significant level of $\beta$-gal reconstitution was observed when $\alpha_{2 \mathrm{c}} \mathrm{AR}-\Delta \mathrm{C}$ 821023 and IR- $\Delta \mathrm{N} 11-75$ were co-expressed, in comparison to that of the non-fusion $\Delta \mathrm{C}$ 82-1023 and $\Delta \mathrm{N} 11-75$ control (Figure 3E). This demonstrated that the contact between $\alpha_{2 c} \mathrm{AR}$ and IR was strong enough to mediate the $\alpha$ complementation between the lacZ mutants. The same was found between $\mathrm{D} 2 \mathrm{DR} \mathrm{L}_{\mathrm{L}}$ and IR, although to a lesser extent (Figure 3E). At this stage, we were uncertain whether the heterodimeric interactions between the three receptors had functional consequences. Comparison of the number of bluestained cells suggested that the receptors IR, $\alpha_{2 c} \mathrm{AR}$, and $\mathrm{D} 2 \mathrm{DR}_{\mathrm{L}}$ would predominantly form homodimers rather than heterodimers with each other under the experimental conditions described here. It further demonstrated that the homodimeric interactions of IR, $\alpha_{2 c} A R$, and $D 2 R_{L}$ were specific and to a large extent at least and not consequences of transmembrane protein overexpression.

Several lines of evidence suggested that constitutive oligomerization is a general feature of GPCRs (4). Such basal oligomerization has been reported for the $\beta 2$-adrenergic $(1,11)$, the dopamine D2 (20), and the insulin (3) 
receptor. We treated the cells co-expressing the fusion receptors with their cognate ligands insulin, brimonidine, and dopamine, but we did not observe a difference in the induction of $\beta$-gal activity. The result suggested that the ligands did not change the constitutive dimerization state of IR, $\alpha_{2 c} \mathrm{AR}$, and $\mathrm{D}_{2} \mathrm{DR}_{\mathrm{L}}$ under the described experi-

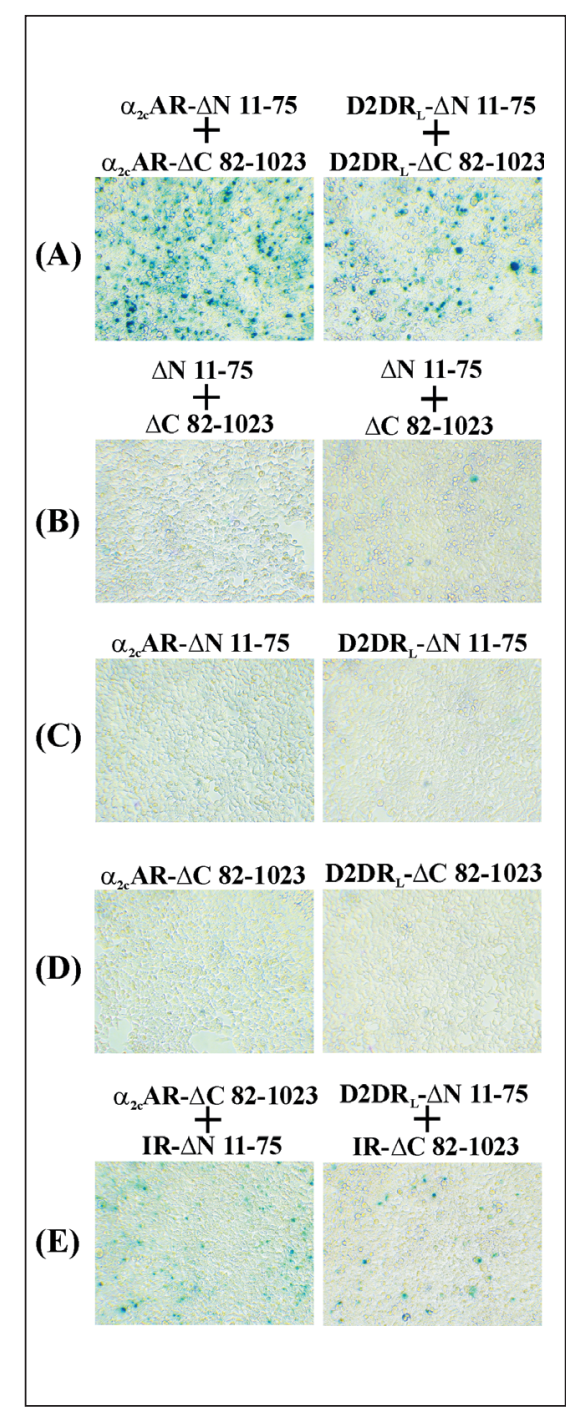

Figure 3. The GPCRs $\alpha_{2 c} A R$ and D2DR ${ }_{\mathrm{L}}$ homodimerize in vivo shown by the $\beta$-gal complementation system using histochemical assays. The enzymatic reactions were stopped after 95 min for the $\alpha_{2 \mathrm{c}} \mathrm{AR}$ experiments, and after $260 \mathrm{~min}$ for the $\mathrm{D} 2 \mathrm{DR} \mathrm{L}_{\mathrm{L}}$ experiments. The monitored $\beta$-gal activity is shown for $\alpha_{2 c} A R$ and D2DR $(A)$, for the co-expressed lac $Z$ deletions $\Delta \mathrm{N} 11-75$ and $\Delta \mathrm{C}$ 82-1023 (B), and for the separately expressed chimeric receptor pairs (C and D). To control for the specificity of the interactions, $\alpha_{2 c}$ AR- $\Delta$ C 821023 was co-expressed with the distantly related IR fused to $\Delta \mathrm{N} 11-75$, and $\mathrm{D} 2 \mathrm{DR}_{\mathrm{L}}-\Delta \mathrm{N} 11-75$ was co-expressed with IR- $\Delta$ C 82-1023 (E). mental conditions (data not shown).

In summary, we present results that a pair of novel lacZ complementation deletions can be used for monitoring interactions between proteins to which they are fused. We demonstrated proof of the principle using membrane pro- tein interaction as a model and provided convincing evidence that the assay could distinguish such interactions from background signals. The application of this method on a large scale could allow the construction of an interaction map between all membrane
(B)

(A)
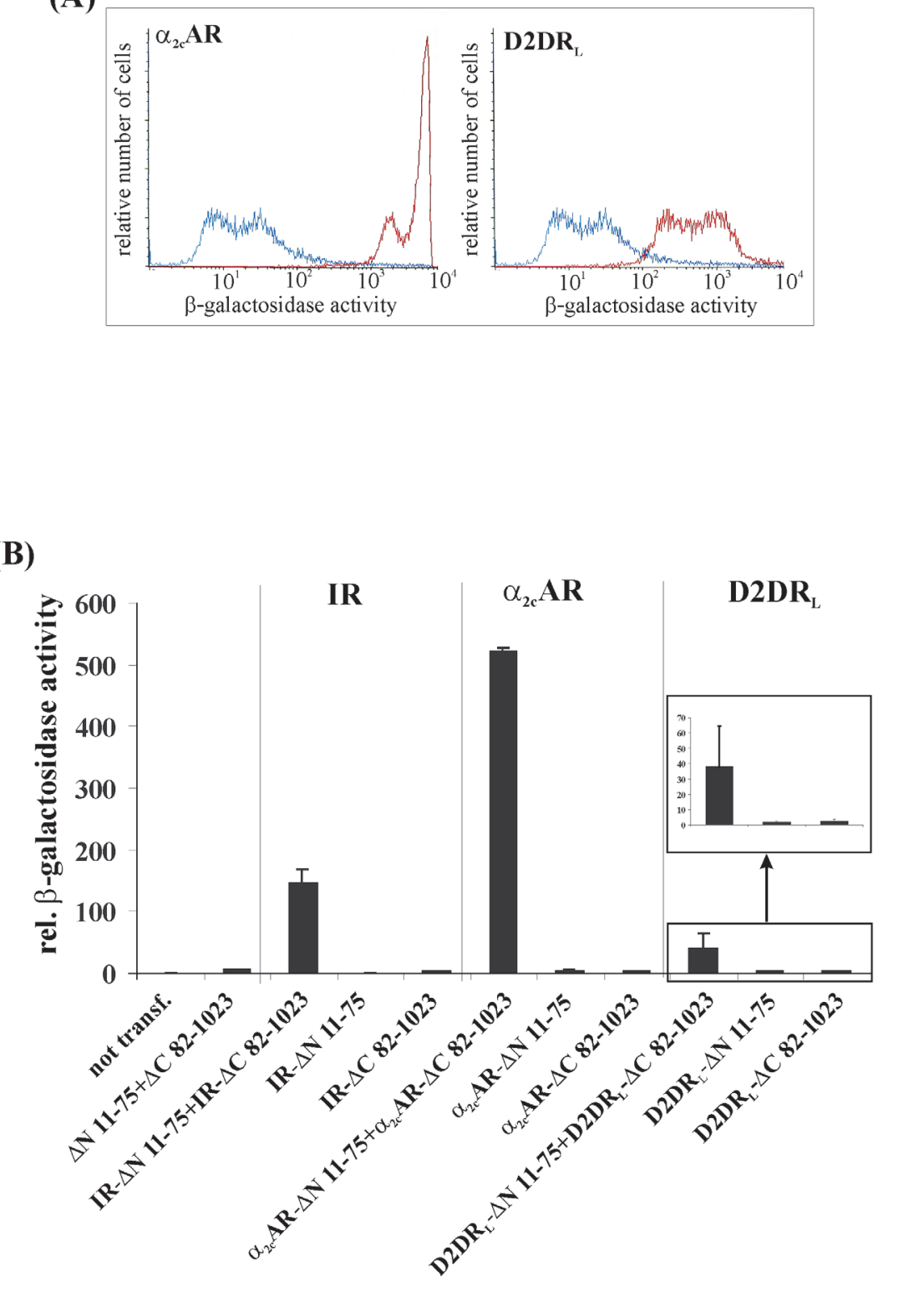

Figure 4. Dimerization of chimeric receptors $\alpha_{2 c} A R$ and D2DR ${ }_{L}$ in HEK-293 cells was examined by FACS analysis and colorimetric measurement. (A) The graphs represent the level of $\beta$-gal activity expressing both $\Delta \mathrm{N} 11-75$ and $\Delta \mathrm{C} 82-1023$ (blue curve), the chimeric receptor pairs $\alpha_{2 \mathrm{c}} \mathrm{AR}-\Delta \mathrm{N} 11-75$ and $\alpha_{2 c}$ AR- $\Delta$ C 82-1023, and D2DR $-\Delta N$ 11-75 and D2DR $-\Delta C$ 82-1023 (red curves). (B) The $\beta$-gal activity was measured for the co-expressed chimeric receptors IR, $\alpha_{2 c} A R$, and D2DR fused to the $\Delta \mathrm{N} 11-75$ and $\Delta \mathrm{C}$ 82-1023 pair. As controls, the non-transfected cells, non-fusion $\Delta \mathrm{N} \mathrm{11-75}$ and $\Delta \mathrm{C} 82-1023$ pair and individually expressed chimeric receptor constructs, were used. The $\mathrm{D} 2 \mathrm{DR} \mathrm{R}_{\mathrm{L}}$ comparison was depicted as an inlet to highlight the different activity levels between the complementing pair and individual constructs. 
proteins. The system has been validated with membrane proteins that dimerize constitutively so far, but it also has the potential to be extended for monitoring ligand-induced interactions. The discovery of the novel peptides $\Delta \mathrm{C} 82$ 1023 and $\Delta \mathrm{N} 11-75$ that can undergo complementation extended our knowledge about the interesting phenomena. The novel peptides could serve as useful tools for exploring the molecular events in the complementation process.

\section{ACKNOWLEDGMENTS}

We thank Dr. Helen M. Blau for providing us with pWZL $\Delta \alpha$ and $\mathrm{pWZL}$ $\Delta \omega$ and Drs. Roberto Maggio for $\mathrm{R} \alpha_{2} \mathrm{pRc} / \mathrm{CMV}$ and Barbara and Ingo $\mathrm{B}$. Leibiger for pRcCMVi HIR(A). This work was supported by a grant from the Center for Genomics and Bioinformatics, Karolinska Institute and Pharmacia Corporation to Z.L.

\section{REFERENCES}

1.Angers, S., A. Salahpour, E. Joly, S. Hilairet, D. Chelsky, M. Dennis, and M. Bouvier. 2000. Detection of $\beta 2$-adrenergic receptor dimerization in living cells using bioluminescence resonance energy transfer (BRET). Proc. Natl. Acad. Sci. USA 97:36843689 .

2.Blakely, B.T., F.M. Rossi, B. Tillotson, M. Palmer, A. Estelles, and H.M. Blau. 2000. Epidermal growth factor receptor dimerization monitored in live cells. Nat. Biotechnol. 18:218-222.

3.Boute, N., K. Pernet, and T. Issad. 2001. Monitoring the activation state of the insulin receptor using bioluminescence resonance energy transfer. Mol. Pharmacol. 60:640-645.

4.Bouvier, M. 2001. Oligomerization of G-protein-coupled transmitter receptors. Nat. Rev. Neurosci. 2:274-286

5.Chio, C.L., G.F. Hess, R.S. Graham, and R.M. Huff. 1990. A second molecular form of D2 dopamine receptor in rat and bovine caudate nucleus. Nature 343:266-269.

6.Ebina, Y., L. Ellis, K. Jarnagin, M. Edery, L. Graf, E. Clauser, J.H. Ou, F. Masiarz, et al. 1985. The human insulin receptor cDNA: the structural basis for hormone-activated transmembrane signaling. Cell 40:747-758.

7.Haima, P., D. van Sinderen, S. Bron, and G. Venema. 1990. An improved $\beta$-galactosidase $\alpha$-complementation system for molecular cloning in Bacillus subtilis. Gene 93:41-47.

8.Karkhoff-Schweizer, R.R. and H.P. Schweizer. 1994. Utilization of a mini-Dlac transposable element to create an a-complementation and regulated expression system for cloning in Pseudomonas aeruginosa. Gene
140:7-15

9.Knipfer, N., L. Nooruddin, and T.E. Shrader. 1998. Development of an $\alpha$-complementation system for mycobacterial promoter analysis. Gene 217:69-75.

10.Leibiger, B., I.B. Leibiger, T. Moede, S. Kemper, R.N. Kulkarni, C.R. Kahn, L.M de Vargas, and P.O. Berggren. 2001. Selective insulin signaling through $\mathrm{A}$ and $\mathrm{B}$ insulin receptors regulates transcription of insulin and glucokinase genes in pancreatic $\beta$ cells. Mol Cell 7:559-570

11.McVey, M., D. Ramsay, E. Kellett, S. Rees, S. Wilson, A.J. Pope, and G. Milligan. 2001 Monitoring receptor oligomerization using time-resolved fluorescence resonance energy transfer and bioluminescence resonance energy transfer. The human delta-opioid receptor displays constitutive oligomerization at the cell surface, which is not regulated by receptor occupancy. J. Biol. Chem. 276:14092 14099.

12.Mohler, W.A. and H.M. Blau. 1996. Gene expression and cell fusion analyzed by lacZ complementation in mammalian cells. Proc. Natl. Acad. Sci. USA 93:12423-12427.

13.Moosmann, P. and S. Rusconi. 1996. $\alpha$ complementation of LacZ in mammalian cells. Nucleic Acids Res. 24:1171-1172

14.Ng, G.Y., B.F. O'Dowd, S.P. Lee, H.T. Chung, M.R. Brann, P. Seeman, and S.R. George. 1996. Dopamine D2 receptor dimers and receptor-blocking peptides. Biochem. Biophys. Res. Commun. 227:200-204

15.Rossi, F., C.A. Charlton, and H.M. Blau. 1997. Monitoring protein-protein interactions in intact eukaryotic cells by $\beta$-galactosidase complementation. Proc. Natl. Acad. Sci. USA 94:8405-8410.

16.Sparrow, L.G., N.M. McKern, J.J. Gorman, P.M. Strike, C.P. Robinson, J.D. Bentley, and C.W. Ward. 1997. The disulfide bonds in the C-terminal domains of the human insulin receptor ectodomain. J. Biol. Chem. 272:29460-29467.

17. Ullmann, A., D. Perrin, F. Jacob, and J. Monod. 1965. Identification, by in vitro complementation and purification, of a peptide fraction of Escherichia coli $\beta$-galactosidase. J. Mol. Biol. 12:918-923.

18.Ullrich, A., J.R. Bell, E.Y. Chen, R. Herrera, L.M. Petruzzelli, T.J. Dull, A. Gray, L. Coussens, et al. 1985. Human insulin receptor and its relationship to the tyrosine kinase family of oncogenes. Nature 313:756-761.

19.Voigt, M.M., S.K. McCune, R.Y. Kanterman, and C.C. Felder. 1991. The rat $\alpha 2-C 4$ adrenergic receptor gene encodes a novel pharmacological subtype. FEBS Lett. 278:45 50

20.Wurch, T., A. Matsumoto, and P.J. Pauwels. 2001. Agonist-independent and -dependent oligomerization of dopamine $\mathrm{D}(2)$ receptors by fusion to fluorescent proteins. FEBS Lett. 507:109-113.

21.Zawarynski, P., T. Tallerico, P. Seeman, S.P. Lee, B.F. O'Dowd, and S.R. George. 1998 Dopamine D2 receptor dimers in human and rat brain. FEBS Lett. 441:383-386.

22.Zhang, Z., W. Zhu, and T. Kodadek. 2000 Selection and application of peptide-binding peptides. Nat. Biotechnol. 18:71-74.
Received 25 September 2002; accepted 6 December 2002.

Address correspondence to:

Dr. Zicai Liang

Center for Genomics and Bioinformatics

Karolinska Institute

Berzelius väg 35

17177 Stockholm, Sweden

e-mail: zicai.liang@cgb.ki.se

\section{For reprints of this or} any other article, contact Reprints@BioTechniques.com 